\title{
ON THE ISSUE OF ORGANIZING PREPARATION AND CONDUCTING DISCUSSIONS IN GERMAN ON LEGAL TOPICS DUE TO THE ACTIVE INVOLVEMENT OF STUDENTS IN THE COLLECTIVE SEARCH FOR TRUTH IN THE CONTEXT OF THE TRANSITION TO A DISTANCE LEARNING FORMAT
}

\author{
Irina Kruse \\ Associate Professor, RUDN University, RUSSIA, kruseirina@rambler.ru
}

\begin{abstract}
Taking into account the fact that the formation of the professional position of future specialists in the field of jurisprudence is a long and multifaceted process, the basic foundations of which are laid from the first semesters of study at the university, at the Department of Foreign Languages of the Law Institute of the Peoples' Friendship University of Russia, a set of academic disciplines was developed and successfully tested, allowing to form a professional position through a system of attitudes towards professional activity through communication using a foreign language as the language of the profession.
\end{abstract}

The main goal of a systematic approach in this direction is to contribute to the formation of the competencies of future lawyers in the field of rule-making, law enforcement, law enforcement, expert consulting and pedagogical activities through a foreign language. The experience of the author of the article confirms that the use of the method of interactive teaching based on a public discussion of problems, during which there is an elucidation and comparison of different points of view and finding a solution to the controversial issue acceptable to all parties, is fundamental in the process of forming the professional position of a specialist in the field rights.

The basis for the implementation of the developed complex is an active-personal approach, which takes into account, first of all, the uniqueness and uniqueness of the personality and contributes to the development of both personal and professional competencies of bachelor students in educational and professional activities.

The purpose of the study of the author of this article is to study the effectiveness of the application of the methodological techniques of the developed complex in the conditions of the remote format of conducting classes in the German language for professional purposes and to make the necessary adjustments, taking into account the transition to a new format of training.

The basis of the materials of the study was an analysis of educational and methodological complexes of Russian and foreign authors in the preparation and conduct of discussions of future lawyers on professional topics in German, methodological and didactic collections developed by teachers of the Department of Foreign Languages of the RUDN University Law Institute in other foreign languages and survey data as Russian and foreign students enrolled in the bachelor's program.

In the course of the study, the methods of quantitative and qualitative analysis, synthesis, sociological observation, questionnaires, generalizations, as well as the method of diagnostic testing were used. The research methodology included questionnaires and statistical data processing.

Particular attention was paid by the author of the article to the observance of the requirements necessary for the fulfillment of educational tasks and exercises during preparation and in the course of discussions: adherence to the algorithm for performing the specified actions, accounting and control of the conditions under which the task is performed, as well as tracking and analyzing the results achieved and missed opportunities.

Keywords: organization of preparation and conduct of discussions, collective search, transition to distance learning, formation of a professional position, future specialist in the field of jurisprudence, personal and professional competencies 


\section{INTRODUCTION}

In the context of the dynamic development of political and legal relations in the era of the widespread introduction of digital technologies, the topic of "using the method of interactive learning based on public discussion of problems" to clarify and compare different points of view and find a solution to a controversial issue acceptable to all parties is fundamental in the process of formation professional position of a specialist in the field of law. A number of documents (Popper, K., 1979; Joung, S., 2003) created the basis for the formation of an algorithm for organizing a discussion (Bayerlein, O, 2015; Lieberkind, J., 2020) in the context of network communication in the framework of educational programs in order to form competence professional communication in German for future specialists in the field of jurisprudence.

An important factor in the formation of the competence to participate in discussions on legal topics in a foreign language is the use of an activity-personal approach (Zelazny, G., 2006; Eismann, V., 2006), which takes into account, first of all, the uniqueness and uniqueness of the personality of the participant in the discussion and contributes to the development of both personal and professional competencies of students under the bachelor's program in the process of implementing educational and professional activities.

The author of this study set a goal to analyze the factors that must be taken into account in the process of using educational and methodological complexes developed at the Department of Foreign Languages of the Law Institute of the Peoples' Friendship University of Russia, in the context of the transition to a distance format of conducting German language classes for professional purposes. Taking into account the identified factors, it was proposed to consider the issue of making the necessary adjustments to the existing teaching aids used.

The above goal required the study author to perform the following tasks:

- Compare the principles of organizing discussions in office and online formats;

- Analyze the difficulties faced by students studying German for professional purposes in preparing and conducting legal discussions;

- Having analyzed the methodological aspects of the new electronic format for learning the German language for professional purposes using network communication, make the necessary adjustments to the materials used in the educational process.

\section{LITERATURE REVIEW}

At the initial stage of the research, the author turned to the analysis of the literature review on the stated topic. The study of the conceptual foundations of the preparation and conduct of discussions on legal problems in a foreign language through the active involvement of students in the collective search for truth has a rich tradition both in domestic and foreign linguodidactics.

One of the principles of modern teaching a foreign language for professional purposes is the use of the method of organizing and conducting discussions as the basis for the accumulation of the thinking process of reasoning, coupled with the formulation of statements, their argumentation and making the final judgment (Kuhn, S., 2001). Many experts in the field of linguodidactics consider discussion as one of the effective methods of team interaction (Allen, M. et al., 2012), the main goal of which is the formation of competencies for analytical and critical thinking (Stokes, A. et al., 2011).

In connection with the transition to a distance learning format for teaching a foreign language for the professional purposes of undergraduate students, the author of the study relies on the experience of specialists in his activities (Bosch, H., 2006; Eliott, M. et al., 2011; Yung, Y. et al., 2017), listing the positions of optimizing the process of organizing, conducting and analyzing discussions within the framework of academic programs. There are publications that analyze various forms of online discussion communication in the process of teaching a foreign language for professional purposes (Belyaeva, I. et al., 2019; Beck, U., 2020).

The analysis of publications on this topic allowed the author of this study to conclude that at the moment, the issues are primarily psychological and pedagogical approaches to solving the problem of using the method of interactive learning based on a public discussion of professional problems to clarify and compare different points of view and find an acceptable for all parties to resolve a controversial issue in the context of the formation of the competence of analytical and critical thinking of future specialists in the field of law require further development and testing. 


\section{METHODOLOGY}

The literature review helped the author of the study to form the basic concept of step-by-step tracking and review of the results obtained, to identify aspects of the analysis and research methods of the stated problem. Taking into account the results obtained during the analysis of the literature on the research topic, the author put forward a hypothesis that increasing the efficiency of using the potential of interactive learning in the course of public discussion discussions on professional topics to clarify and compare different points of view and find what is acceptable for all parties resolving a controversial issue, the following positions contribute:

- Creation of comfortable psychological and pedagogical conditions in order to form students' motivation to use various sources for training, assistance in organizing and analyzing discussion discussions in the context of distance foreign-language professional education in bachelor's degree;

- Providing comprehensive pedagogical support in the creation of individual trajectories of preparation and participation of each student in the interactive process of learning a foreign language for professional purposes, helping to resolve the emerging contradictions between the level of educational activity dictated by the curriculum and the real capabilities and needs of the student himself;

- Effective use of all components of the TEAMS platform, which ensures the necessary technical level of implementation of electronic technologies in the educational process and stimulates the interaction of all participants in the process of mastering a foreign language for professional purposes on the basis of a high degree of interactivity.

Regular interaction both in the whole study group and in mini-groups in an electronic environment with the help of synchronous and asynchronous TEAMS tools contributes to the formation of the ability of virtual communication, opens up prospects for preparing and conducting online discussions that contribute to the formation of the competence of analysis, comparison and argumentation.

In the process of research on the stated topic, the author of the article paid attention not only to identifying factors contributing to an increase in the efficiency of preparation and conducting discussions in a foreign language on legal topics in a distance format, but also to the potential of the environment, with a predominant socio-cultural component influencing the formation of an activity approach in the framework of an individual educational trajectory.

The conducted research was based on a qualitative approach to the analysis of the results obtained in the process of interviews and questionnaires, as it made it possible to track and record both requests and perceptions, as well as a qualitative assessment by students of the research problem in a real situation. The materials of the study were based on the data of interviews and answers during a survey of students under the bachelor's program of the Department of Foreign Languages of the Law Institute of the Peoples' Friendship University of Russia. A total of 32 students took part in the study.

In the course of this study, not only empirical results worked out over the past two years were used, but also the results obtained based on comparative and systemic methods, as well as the use of data comparison. In order to confirm the validity of the collected material, in the course of the study, survey methods were used questionnaires, assessment of the formulated parameters individually, by the entire study group and in pairs, followed by a general assessment and formulation of recommendations for making the necessary additions and changes to the academic program.

\section{RESULTS AND DISCUSSION}

Based on the analysis of domestic and foreign literature and the results of the study, the author of the article shares the position of those who argue that the online discussion form helps students to express alternative points of view without fear of speaking in public, formulate a vision of the problem from a new point of view, draw conclusions, to reasonably build a statement based on the received initial data and illustrative examples in a distance format. A positive component of each online discussion is the impossibility of data loss, since the "forum" stores a record of all speeches, statements and spoken remarks, messages that are stored in the cloud virtual space on the TEAMS platform and are available via a link for listening by any user (Hew, K. et al., 2010; Yamagata-Lynch, L., 2014).

An important point that deserves special attention is that a part of the student audience that had not previously taken part in offline discussions due to fear of making grammatical and lexical errors, as well as misusing legal terms in a foreign language, were able to formulate online ideas and suggestions, avoiding the dominance of fellow students who speak the foreign language being studied at a higher level. 
In the course of the study, interviews were also conducted with colleagues with experience in preparing and organizing a discussion in a distance format. $80 \%$ of the teachers surveyed believe that students are extremely passive in conducting the preparatory stage of the discussion, $45 \%$ note the superficiality of their statements during discussions, for $77 \%$ the main indicator of failed moments in the discussions is the low grammatical level of students' statements, and the incorrect use of lexical constructions was noted by $62 \%$ participating in the survey.

Table 1 shows the results of students' answers to the questionnaire questions due to the reasons for inactive participation in discussion discussions of professional topics in a foreign language (the number of respondents is 32 people).

Table No. 1

Reasons for non-participation in legal discussions in German for undergraduate students (Department of Foreign Languages, RUDN Law Institute)

\begin{tabular}{|l|l|l|}
\hline № & \multicolumn{1}{|c|}{ parameters } & $\begin{array}{l}\% \\
\text { significance }\end{array}$ \\
\hline 1. & lack of time to work out the proposed material for discussion & $52 \%$ \\
\hline 2. & lack of ideas on the topic of discussion & $33 \%$ \\
\hline 3. & $\begin{array}{l}\text { fear of making mistakes in the wording of a statement in a } \\
\text { foreign language }\end{array}$ & $65 \%$ \\
\hline 4. & technical problems with turning on the camera and microphone & $12 \%$ \\
\hline 5. & problems with posting material in the chat & $22 \%$ \\
\hline 6. & failure to comply with preparatory instructions & $30 \%$ \\
\hline
\end{tabular}

The analysis of the results of the survey of students made it possible to identify those moments that are currently taken into account by the teachers of the Department of Foreign Languages of the Law Institute when drawing up programs for studying a foreign language for professional purposes in a bachelor's degree. And first of all, these are issues related to the provision of methodological and didactic assistance to students in drawing up individual learning paths that contribute to autonomy in the process of learning a foreign language for professional purposes and participation in discussions on legal topics. Work on the formation of an algorithm for the work of students with specialized sites requires special attention.

\section{CONCLUSION}

The data obtained indicate that the majority of the interviewed students under the bachelor's program at the Department of Foreign Languages of the RUDN Law Institute productively use the potential of foreign language educational activity to participate in discussions on professional topics. The moments identified by the author of the article that affect the degree of activity in the process of preparing and conducting discussion discussions formed the basis for adjusting the academic programs for training specialists in the field of jurisprudence (bachelor's degree).

More than half of those who took part in the survey (72\%) students positively assess the potential inherent in the method of interactive learning based on public discussion of problems to clarify and compare different points of view and find a solution to the controversial issue acceptable to all parties, allowing to expand and deepen the range of knowledge in a foreign language for professional purposes. Equally important is the adaptive component of this process, which allows each student in the bachelor's degree to meet the challenges of modern society and the changed social and economic conditions.

The author of the study expresses gratitude to colleagues and students who took part in the survey and discussion of the potential of interactive learning based on public discussion of professional problems in a foreign language. 


\section{ACKNOWLEDGMENT}

The publication has been prepared with the support of the RUDN University program under 5-100 Russian Academic Excellence Project.

\section{REFERENCE LIST}

Allen, M., Tay, E. (2012). Wikis as Individual Student Learning Tools. International journal of information and communication technology education: an official publication of the Information Resources Management Association 8(2):61-71 DOI: 10.4018/jicte.2012040105

Bayerlein, O. (2015). Campus Deutsch als Fremdsprache Präsentieren und diskutieren, B2-C1 Hueber Verlag 2015

Beck, U. (2020). Globalization of Modern Education ttps://www.assignmentexpert.com/blog/globalization-ofmodern-education/

Belyaeva, I., Samorodova, E.,. Voron, O., Zakirova, E. (2019). Analysis of Innovative Methods' Effectiveness in Teaching Foreign Languages for Special Purposes Used for the Formation of Future Specialists' Professional Competencies Education Sciences 9(3):171 DOI: 10.3390/educsci9030171 License CC BY

Bosch, H. (2006). Personalized Course Delivery: An Empirical Analysis of the Feasibility of Adapting Distance Learning Courses to Individual Students' Learning Preferences DOI: $10.5367 / 000000006778702328$

Eismann, V., (2006). Erfolgreich bei Präsentationen Goethe-Institut, Cornelsen 2006 https://www.andersdenken.at/praesentationstechnik-tipps/

Eliott, M., Howard, P. (2011). Instructors' considerations for assessing individual students' learning in teambased coursework. Conference: Australasian Association for Engineering Education

Hew, K., Cheung, W. \& Ng, C., (2010). Student contribution in asynchronous online discussion: A review of the research and empirical exploration. Instructional Science, №38 (6), p. 571-606.

Kuhn, S. (2001). Learning from the Architecture Studio: Implications for Project-Based Pedagogy. The International Journal of Engineering Education, 17 (4). Pp.349-350 // The offi cial website of the International Journal of Engineering Education. URL: http://www.jjee.

Lieberkind, J. (2020). Democracy and togetherness: between students' educational and political status- a study of primary and lower secondary education in Denmark. Multicultural Education Review, 12(21):1-14 DOI: $10.1080 / 2005615 X .2020 .1720134$

Popper K.R. The Aim of Science // Popper K.R. Objective Knowledge. An Evolutionary Approach. Oxford: Clarendon Press, 1979. Ch. 5. pp. 191-205

Stokes, A., Wilson, E. (2011). Catering for Individual Student Learning Preferences In Economics DOI: 10.19030/ajbe. v2i9.4607

Yamagata-Lynch, L. (2014). Blending online asynchronous and synchronous learning. The International Review of Research in Open and Distributed Learning, 15(2), 189- 212. URL: http://www.irrodl.org/index.php/irrodl/article/view/1778/2889

Joung, S. (2003). The Effects Of High-Structure Cooperativ Versus Lowstructure Collaborative Desigh On Online Debate In Terms Of the Hawaii University at Manoa. P. 13. URL: http://www.ics.hawaii.edu/research/ ics-tr-library/ICS1993-01-01.pdf/view

Yung, Y., Lillian, C., Chan, K. (2017). Statistically Modeling Individual Students' Learning Over Successive Collaborative Practice Opportunities: Learning Over Successive Collaborative Practice Opportunities Journal of Educational Measurement 54(1):123-138 DOI: 0.1111/jedm.12137

Zelazny, G. (2006). Say It with Presentations: How to Design and Deliver Successful Business

Presentations. McGraw-Hill Education; 2nd edition 